\title{
IDEAL CONDITION OF THE CRIMINAL JUSTICE SYSTEM IN AN EFFORT TO DERADICALIZE THE CRIMINAL ACT OF TERRORISM TO ACHIEVE SUBSTANTIAL JUSTICE
}

\author{
KONDISI IDEAL SISTEM PERADILAN PIDANA DALAM UPAYA \\ DERADIKALISASI TINDAK PIDANA TERORISME UNTUK \\ MEWUJUDKAN KEADILAN SUBSTANSIAL
}

\author{
Muhammad taufiq* \\ taufiq_advocate007@yahoo.co.id
}

(Diterima pada: 05-06-2017 dan dipublikasikan pada: 01-12-2017)

\begin{abstract}
The purpose of this study is to examine how law enforcement and prevention efforts and Deradicalisation of terrorism acts in the perspective of Human Rights, Local Wisdom, and realizing a Substantial Justice Criminal System in Indonesia. The approach method used in this scientific work is the normative juridical approach method. With the presentation of data qualitatively. This study emphasizes that the law as a means of law enforcement in Indonesia, especially in the enforcement of Law on Combating Terrorism Crime. The result of this research is that it can be concluded that local wisdom in communal society can be used as media to optimize and strengthen the role of society in countering radical groups and terrorists can be an option to minimize the negative effects caused by the approach of security (hard approach).
\end{abstract}

Keywords: Terrorists, Terrorism, Human Rights, Local Wisdom

\begin{abstract}
ABSTRAK
Tujuan dari penelitian ini adalah untuk mengkaji mengenai bagaimana penegakan hukum dan upaya penanggulangan dan Deradikalisasi tindak pidana terorisme dalam perspektif Hak Asasi Manusia, Kearifan Lokal, dan mewujudkan Sistem Peradilan Pidana yang berkeadilan Substansial di Indonesia. Metode pendekatan yang digunakan dalam karya ilmiah ini adalah metode pendekatan yuridis normatif. Dengan penyajian data secara kualitatif. Penelitian ini menitik beratkan bahwa hukum sebagai sarana penegakan hukum di Indonesia, khususnya dalam penegakkan hukum Pemberantasan Tindak Pidana Terorisme. Hasil dari penelitian ini adalah bahwa dapat disimpulkan Kearifan lokal dalam masyarakat komunal dapat dijadikan media untuk mengoptimalkan dan menguatkan peran masyarakat dalam penanggulangan kelompok radikal dan teroris dapat menjadi pilihan untuk meminimalisasi efek negatif yang ditimbulkan oleh pendekatan keamanan (hard approach).
\end{abstract}

Kata Kunci : Terorisme, Penegakan Hukum, Hak Asasi Manusia, Kearifan Lokal

\footnotetext{
* Dosen Pascasarjana Fakultas Hukum Universitas Djuanda Bogor, Jl.Tol Ciawi No I, Kotak Pos 35 Bogor 16770
} 


\section{A. Pendahuluan}

Persoalan terorisme tidak mudah diurai, apalagi dituntaskan sampai keakarnya sehingga diibaratkan; ketika satu teroris berhasil dimatikan oleh polisi, 1000 yang lain muncul. Indonesia seperti tidak pernah kehabisan stok teroris, mereka terus ada di lingkungan kita. Adanya jaringan baru menjadi bukti bahwa teroris belum gagal bahkan telah meraih kemenangan dari sisi lain, yakni kemenangan wacana (gagasan dan ideologis).

Asumsinya sederhana, tatkala penguburan para pelaku bom bunuh diri disiarkan massa media (televise), sebagian masyarakat mempelakukan dan menganggapnya sebagai pahlawan (pembela) Islam. Hal ini artinya, paham redikalisme agama telah kuat dan mengakar, mengaburkan nilai-nilai ideologi Pancasila karena dalam prakteknya nilai-nilai ideologi Pancasila dianggap gagal mewujudkan keadilan dan tersandera oleh praktek liberalis dan komunism.

Para teroris selalu menyalahkan bukan hanya agama lain, tapi juga penganut mainstream dalam agamanya (Islam) karenadianggap telah sesat karena berkolaborasi dengan Barat, terutama Amerika. Bom bunuh diri adalah tindakan yang sah menurut keyakinan para teroris, sebagaimana pernah dituturkan Imam Samudra. Jadi adalah kejahatan yang mengerikan ketika teroris sudah membajak agama dan menjadikan perjuangannya seolah-olah selaras dan tidak bertentangan dengan agama yang dianutnya. Bahkan tindakan kekerasan lewat bom dianggap sebagai bentuk perjuangan yang mulia. Inilah tugas pendidikan Islam yang bisa dikatakan sangat berat memberikan perspektif lain tentang jihad dan pahlawan Islam itu seperti apa sebab pertarungan wacana Islam demikian terbuka.

Pemuka agama seharusnya bukan sekedar beralibi bahwa 'teror tidak berhubungan dengan agama' belaka, namun juga harus peka dan massif dalam menguatkan pemahaman ummat nya bahwa penafsiran (pemahaman) keagamaan yang ekstrim dan radikal hanya akan menjebak penganutnya saling berperang. Memberikan keteladanan serta menyerukan kebajikan dengan senantiasa berbuat baik kepada siapa dan apapun menjadi jargon dalam setiap kampanye, khutbah, ceramah dan siraman rohaninya. Menyimak alasan dan penyebab terjadinya teror di Indonesia (bahkan seluruh dunia), hanya karena kebencian yang teramat besar pada 'barat (Amerika)' beserta jaringannya yang tidak menguntungkan agama (ideologi) tertentu dengan kebijakan dan strateginya menguasai dunia.

Tumbuhnya benih-benih radikalisme berasal dari sekumpulan kelompok, doktrin ideologis bahkan dunia pendidikan sehingga yang harus di perbaharui adalah menyimak kembali materi pergumulan, bagaimana cara penyampaian dan apa tujuan dorongan ideologis dimaksud. Pengetahuan keagamaan kita cenderung "hanya pada tataran pengetahuan beribadah dan bukan pengamalan beribadah".

Ketika gerakan terorisme mengusung jihad ofensif di dalam memahaminya, misalnya melalui suicide bombing, teror dengan kekerasan dan sebagainya, maka tentu harus diajarkan tentang makna jihad secara memadai. Pengertian jihad yang moderat yakni bekerja keras untuk mencapai tujuan yang sangat baik terutama untuk kemaslahatan umat. Sehingga janganlah jihad tersebut dihapus dari mata ajaran karena konotasinya yang disalahartikan. Namun, justru harus ada upaya yang memadai untuk memberikan penjelasan secara memadai. Tentu saja juga harus ada seorang guru atau ustadh atau dosen yang bias menjelaskan mengenai makna jihad yang bernuansa rahmatan lil alamin. Makanya, para pendidikpun perlu diseleksi secara memadai agar tidak mengajarkan Islam atau agama apapun yang sesuai dengan konsepsi kaum radikalis, demikian pula yang menjadi tugasnya para ulama dan pemuka agama. 
Beberapa aspek dan pendekatan yang perlu dipertimbangkan dalam menangkal terorisme secara menyeluruh, yaitu;. Pertama, aspek ideologis karena akar terorisme ialah pemahaman ideologi yang salah, maka perhatian aparat tidak boleh hanya tertuju pada bentuk terornya saja. Kedua, aspek regulasi karena untuk memberantas terorisme tentu perlu aturan yang cukup agar aparat bisa bergerak di lapangan dengan langkahlangkah yang terukur, tangan sampai langkah yang dilakukan aparat justru dinilai melanggar HAM. Ketiga, aspek political will dari Negara untuk menggerakkan

semua elemen bangsa Indonesia dalam rangka melakukan penanganan terorisme secara terpadu.

Terpadu artinya tidak bias hanya mengandalkan aparat keamanan seperti polisi, tetapi sekaligus melibatkan dunia pendidikan dari tingkat menengah sampai perguruan tinggi; sebab seperti kita ketahui belakangan aktivitas teroris dan radikalisasi yang berbasiskan agama bergerak di institusi pendidikan, baik lembaga pendidikan berlatar belakang keagamaan maupun tidak. Pelestarian nilai-nilai budaya dan kearifan lokal yang toleran antar sesama sahabatnya terancam punah karena gelombang globalisasi, mempersempit jarak pemisah antar si kaya dan si miskin, antar penguasa dan yang dikuasai, antar raja dengan hambanya; adalah solusi bijak dalam pendekatan sosial budaya dan keagamaan.

Dari latar belakang tersebut penulis menyimpulkan suatu rumusan masalah yang akan dikaji didalam penelitian ini yaitu:

1. Bagaimana mekanisme penanggulangan terorisme dari aspek kebijakan local?

2. Bagaimana Peran Serta Sistem Peradilan Pidana dalam upaya untuk menanggulangi tindak pidana terorisme untuk mewujudkan keadilan substansial?

Metode pendekatan yang diterapkan dalam karya ilmiah ini adalah metode pendekatan yuridis normatif. Dengan penyajian data secara kualitatif. Penelitian ini menitik beratkan bahwa hukum sebagai sarana penegakan hukum di Indonesia, khususnya dalam penegakkan hukum Pemberantasan Tindak Pidana Terorisme.

\section{B. Mekanisme Penanggulangan Terorisme Dari Aspek Kebijakan Lokal}

Terkait penanganan terorisme di dunia, setiap negara yang di bawah PBB mempunyai kewajiban untuk turut andil dalam memerangi terorisme yang sekaligus sebagai upaya untuk menjaga perdamaian dunia. Dalam upaya-upaya memerangi terorisme tersebut perlu diperhatikan prinsip-prinsip HAM dan tidak melakukan tindakan yang pragmatis.

MK memberi istilah terhadap aksi terorisme sebagai kejahatan biasa yang sangat kejam. Terorisme tidak sama dengan kejahatan genosida, kejahatan terhadap kemanusiaan, kejahatan perang, juga kejahatan agresi. MK sendiri mengakui bahwa putusan itu diambil karena belum ada landasan yuridis bahwa kejahatan terorisme juga tersangkut paut dengan kejahatan luar biasa. ${ }^{1}$

Dalam upaya menanggulangi aksiaksi terorisme diperlukan suatu penguatan terhadap peran penegak hukum khususnya di Indonesia dengan menitikberatkan pada institusi keamanan, dalam hal ini kepolisian sebagai bentuk keseriusan pemerintah dalam menghadapi aksi serangan maupun ancaman terorisme. Pemerintah Indonesia disponsori oleh Australia oleh beberapa pemerintah asing khususnya pemerintah Australia dan Amerika Serikat membentuk Detasemen Khusus (Densus) 88 Anti Teror Polri sebagai terdepan dalam pemberantasan terroisme. Tugas pokoknya lebih banyak menitikberatkan untuk segera membongkar kasus pemboman, menangkap pelaku, dan membongkar jaringan teroris yang berada di belakang aksi teror.

\footnotetext{
${ }^{1}$ Usman Hamid, Pengembangan Pemikiran dan Solusi Strategis Penanggulangan Aksi Terorisme dalam Perspektif Hukum dan HAM, hlm 7
} 
Polisi mempunyai kewenangan dalam penanggulangan terorisme, namun juga ada batasan-batasan nyata yang mengatur aspek dari kepolisian itu sendiri. Kekuatan diskresi yang melekat dalam tugas mereka juga harus diikuti dengan proses pemahaman untuk menghormati dan berbagai ketetapan yang sudah disepakati dalam standar HAM yang sudah diakui dunia internasional. Sudah seharusnya tantangan-tantangan yang akan dan telah dihadapi oleh polisi dijalankan dalam koridor hukum dan standar HAM internasional.

Kearifan lokal merupakan suatu unsur penting dalam penanggulangan radikalisme terorisme yang kini menggunakan kekuatan dalam upaya mencapai keinginannya. Kearifan Lokal memiliki daya tarik tersendiri dalam menangkal fenomena ini karena hal tersebut sulit tinggalkan oleh setiap orang dimana ia tumbuh berkembang.

Secara umum masyarakat Indonesia sangat berbeda dengan masyarakat luar. Masyarakat Indonesia misalnya sangat menghargai persaudaraan dan keakraban dan saling menghormati. Dalam konteks seperti diatas erat hubungannya dengan pemberantasan radikalisme dan terorisme sebab radikalisme dan terorisme mengabaikan hal-hal seperti ini. Terorisme misalnya sudah tidak lagi memperhatikan kerukunan dalam satu masyarakat bahkan dalam satu keluargapun mereka bisa menentang jika berbeda. Ini tentu sangat berbeda dengan kultur kita dan setiap kearifan lokal di tanah air yang sangat menghargai persaudaraan dan kekeluargaan.

Kearifan lokal dalam masyarakat komunal dapat dijadikan media untuk mengoptimalkan dan menguatkan peran masyarakat dalam penanggulangan kelompok radikal dan teroris dapat menjadi pilihan untuk meminimalisasi efek negatif yang ditimbulkan oleh pendekatan keamanan (hard approach). Untuk program deradikalisasi, beberapa hal dapat dijalankan: a. Optimalisasi partisipasi tokoh agama dalam menjaga tuntutan syariat Islam tidak berkembang menjadi ekstremisme juga terorisme. Hasil riset yang dilakukan BNPT tahun 2013 sangat jelas menunjukkan signifikansi tokoh agama dalam proses diseminasi gagasan. Ini menunjukkan peranan tokoh agama sangat penting dalam proses penyebaran gagasan yang berhubungan dengan narasi Islamisme.

b. Menjaga dan mewaspadai lembagalembaga keagamaan lokal dan nasional, institusi yang memperjuangkan penerapan syariat Islam, agar tidak berkembang menjadi tempat bersemainya ekstremisme dan terorisme.

c. Optimalisasi peran lembaga keagamaan moderat, seperti Nahdlatul Ulama, Muhammadiyah, dan Persis. Keterlibatan lembaga keagamaan lokal, Komite Persiapan Penegakkan Syariat Islam (KPPSI) dan Wahdah Islamiyah, juga perlu ditingkatkan. Keduanya merupakan lembaga yang berpengaruh di tengah-tengah masyarakat Sulawesi Selatan.

d. Kampanye anti-radikalisme melalui lembaga pendidikan. Perguruan Tinggi merupakan lembaga strategis yang bisa dijadikan media anti radikalisme dan terorisme. Perguruan tinggi (universitas) menjadi salah satu tempat berkembangnya gagasan Islamisme yang dikembangkan melalui seminar serta halaqah oleh kelompok Islamisme. Oleh sebab itu, Kampus juga bisa menjadi tempat strategis bagi penyebaran kontra-narasi Islamisme.

e. Revitalisasi kearifan lokal. Menumbuhkan semangat kolektivitas 
dan rasa empati yang tinggi terhadap sesama masyarakat. Nilai-nilai ini bisa dijadikan suatu dasar untuk membingkai (framing) aksi terror dan kekerasan sebagai perbuatan yang memalukan serta merendahkan harga diri.

f. Kampanye anti radikalisme dan terorisme melalui berbagai media. Mengunakan buku dan brosur, pesan singkat (SMS) merupakan media yang juga banyak dimanfaatkan oleh generasi muda dalam memperoleh pengetahuan dan informasi. Oleh karena itu, SMS bisa menjadi media yang efektif untuk melakukan deradikalisasi kalangan muda.

UU terorisme memberikan justifikasi terhadap sejumlah pelanggaran hak asasi manusia. Hak tersebut adalah hak-hak non derogable rights atau yang tidak dapat dikesampingkan. seperti hak hidup, hak bebas atas penyiksaan dan hak persamaan di dalam hukum. Sikap yang tegas dalam menghadapi terorisme sangat di perlukan, namun perlu diperhatikan bahwa dalam menangani sebuah aksi terorisme yang dapat dikategorikan sebagai kondisi darurat, sikap yang over responsif dapat mempengaruhi negatif terhadap perlindungan, pemenuhan, dan pemajuan hak asasi manusia. ${ }^{2}$

\section{Peran Serta Sistem Peradilan Pidana Dalam Upaya Untuk Menanggulangi Tindak Pidana Terorisme Untuk Mewujudkan Keadilan Substansial}

Pengertian Sistem peradilan pidana (Criminal Justice System), disebut juga

\footnotetext{
${ }^{2}$ T. Nasrullah, Tinjauan Yuridis Aspek Hukum Materil Maupun Formil Terhadap UU No. 15/2003 Tentang Pemberantasan Tindak Pidana Terorisme, Jurnal Kriminologi Indonesia Vol.4 No.I September 2005: 65-76, hlm 75
}

dengan istilah law enforcement system, ${ }^{3}$ karena di dalamnya mengandung suatu pemahaman, bahwa pada dasarnya apa yang dilakukan oleh lembaga-lembaga itu merupakan usaha konkrit untuk menegakkan aturan-aturan hukum abstrak. Dengan demikian, dapat disimpulkan, bahwa sistem peradilan pidana merupakan suatu komponen (subsistem) peradilan pidana yang saling terkait/tergantung satu sama lain dan bekerja untuk mencapai tujuan, yaitu untuk menanggulangi kejahatan sampai batas yang dapat ditoleransi oleh masyarakat. Secara eksplisit, makna sistem peradilan pidana itu menggambarkan adanya keterpaduan antara sub-sub sistem yang ada dalam suatu peradilan, sehingga dikenal dengan istilah sistem peradilan pidana terpadu (Integrated Criminal Justice System). ${ }^{4}$

Sebagaimana disebutkan oleh Soetandyo Wigjosoebroto ${ }^{5}$, bahwa tidak ada konsep yang tunggal tentang apa yang disebut dengan hukum itu. Menurut Pendapatnya dalam sejarah pengkajian hukum, tercatat sekurang-kurangnya ada lima konsep. Pertama, hukum dikonsepkan sebagai asas moralitas atau asas keadilan yang bernilai universal dan menjadi bagian inheren sistem hukum alam. Kedua, hukum dikonsepkan sebagai kaidah-kaidah positif yang berlaku pada suatu waktudan tempat tertentu, sebagai produk eksplisit suatu sumber kekuatan politik tertentu yang berlegitimasi. Ketiga, hukum dikonsepkan sebagai institusi sosial yang riil dan fungsional dalam sistem kehidupan bermasyarakat. Dalam hal ini hukum berperan dalam proses pemulihan ketertiban, penyelesaian sengketa, maupun

3 Bryan A. Garner. 2004. Black's Law Dictionary. Edisi Delapan. Amerika Serikat: West Publishing CO, Hlm. 901

${ }^{4}$ Mahrus Ali. 2007. Sistem Peradilan Pidana Progresif: Alternatif dalam Penegakkan Hukum Pidana, dalam Jurnal Ilmu Hukum Vol. 14 No. 2 April 2007 Hlm. 217

5 Soetandyo Wigjosoebroto. 1980. Hukum dan Metode-Metode Kajiannya. Jakarta: BPHN. Hlm: 2 
dalam proses pengarahan dan juga pembentukan pola-pola perilaku yang baru.

Penulis dalam hal ini mengacu kepada konsep ketiga dari yang di sebutkan oleh Soetandyo di atas, yaitu menggunakan pendekatan sosiologis. Sebagaimana diketahui dewasa ini studi hukum masih terfokus pada analisis hukum dogmatis. Penulis berpendapat harus ada perubahan pemahaman tersebut maka akan tercapai suatu sistem peradilan pidana yang ideal.

Dalam Sistem yang ideal tersebut salah satunya ialah hak atas bantuan hukum. Hak atas bantuan hukum (legal assistance/legal aid) adalah hak sipil yang telah diterima secara universal dan dijamin oleh International Covenant on Civil and Political Rights (ICCPR). Pada Pasal 14 ayat (3) ICCPR disebutkan: ${ }^{6}$

Suatu negara hukum tentu mengakui dan melindungi hak individu. Pengakuan terhadap hak individu dijamin dalam asas persamaan di hadapan hukum. Dan jika ada persamaan di hadapan hukum (equality before the law), maka ada pula persamaan perlakuan (equal treatment) bagi semua orang. Persamaan di hadapan hukum ini menjamin adanya akses untuk memperoleh keadilan (access to justice). ${ }^{7}$

Tobias dan Petersen mengatakan bahwa "due process of law", yang berasal dari dokumen Magna Charta, 1215, merupakan "constitutional guaranty... that no person will be deprived of life, liberty or property for reasons that are arbitrary." Proses hukum ini "...protects the citizen against arbitrary actions of the government." Karena itu inti dari proses hukum yang adil dan ideal adalah:

\footnotetext{
${ }^{6}$ Aidul Fitriciada Azhari. UU Bantuan Hukum dan Peran LBH Kampus. Makalah Disampaikan pada Seminar Nasional "Prospek Lembaga Bantuan Hukum Pasca disahkannya UU Bantuan Hukum" yang diselenggarakan oleh Fakultas Hukum Universitas Muhammadiyah Surakarta bekerjasama dengan Indonesian legal Recourse Center (ILRC) di Surakarta pada Sabtu, 14 April 2012 Hlm. 1

${ }^{7}$ Frans H. Winarta. 2009. Suara Rakyat Hukum Tertinggi. Jakarta: Kompas. Hlm. 15
}

a. Tersangka (maupun terdakwa) berhak untuk didengar pandangannya tentang bagaimana peristiwa yang dituduhkan padanya itu terjadi (hearing);

b. Dalam pemeriksaan (sejak pertama kali di Kepolisian) ia selalu bdapat didampingi oleh penasihat hukum (legal counsel);

c. Terdakwa berhak mendapat kesempatan yang seluas-luasnya untuk menyusun dan mengajukan pembelaannya (defenses);

d. Adalah kewajiban penuntut umum untuk membuktikan kesalahan terdakwa dengan bukti-bukti yang sah menurut hukum (legal evidence);

e. Pengadilan yang memeriksanya haruslah bebas dari tekanan siapa pun dan dengan hakim yang tidak berpihak (a fair and impartial court). ${ }^{8}$

Penulis berpegang pada prinsipprinsip keadilan yang dikemukakan John Rawls, dimana setiap orang memiliki klaim yang sama untuk memenuhi hak-hak dan kemerdekaan-kemerdekaan dasarnya yang kompatibel dan sama jenisnya untuk semua orang, serta kemanfaatan sebesar-besarnya bagi anggota-anggota masyarakat yang paling tidak diuntungkan. Selain prinsip di atas menurut Penulis dalam Sistem Peradilan Pidana yang ideal juga harus memperhatikan prinsip lain yang dikemukakan oleh John Rawls yaitu mampu mengatur kembali kesenjangan social ekonomi yang terjadi sehingga dapat member keuntungan yang bersifat timbale balik (reciprocal benefits) bagi setiap orang, baik mereka yang berasal dari kelompok beruntung maupun tidak beruntung. Hal yang diutamakan dalam sistem peradilan pidana yang ideal adalah untuk mencapai keadilan. Inilah yang sejalan dengan Gustav Radbruch yang menyatakan bahwa cita hukum tidak lain dari pada keadilan. Radbruch mengajarkan bahwa yang harus digunakan asas prioritas, yakni prioritas

\footnotetext{
${ }^{8}$ Abdul Latief. 2010. Jaminan UUD 1945 dalam Proses Hukum yang Adil, dalam Jurnal Konstitusi Volume 1 Nomor 1 Februari 2010 Hlm. 59
} 
pertama selalu "keadilan", barulah "kemanfaatan", dan terakhir barulah "Kepastian".

Pelaksanaan sistem peradilan yang baik sendiri ialah terlaksananya beberapa prinsip umum sebagai standar minimum dalam penerapan sistem peradilan yang terintegrasi dengan baik. Standar minimum termaksud adalah: ${ }^{9}$

\section{a. Equality Before The Law}

Prinsip yang dirumuskan dalam pasal 28 D ayat (1) Amandemen Kedua UUD 1945 dan Pasal 5 ayat (1) UU No. 48 Tahun 2009 ini merupakan asas yang bersifat universal. Pasal 7 Universal Declaration of Human Rights menjelaskan bahwa "shall are equal before the law and are entitled without discrimination to equal protection of law".

\section{b. Due Process of Law}

Negara sebagai pemegang kekuasaan tertinggi memiliki kewenangan penuh untuk melakukan proses peradilan yang adil dan tidak memihak. Oleh karenanya kekuasaan ini perlu dibatasi agar tidak terjadi penyalahgunaan wewenang. Atas ini tercermin dari pasal 6 ayat (1) dan Pasal 7 UU No. 48 Tahun 2009 tentang Pokok-Pokok Kekuasan Kehakiman. Due Process of Law pada dasarnya bukan semata-mata mengenai rule of law, akan tetapi merupakan unsure yang esensial dalam penyelenggaraan peradilan yang intinya adalah bahwa ia merupakan"...a law which hears before it condemns, which proceeds upon inquiry, and renders judgement only after trial..." Pada dasarnya yang menjadi titik sentral ialah perlindungan hak-hak asasi individu terhadap arbitrary action of the government.

\footnotetext{
9 http://www.komisihukum.go.id.Administrasi Peradilan-Laporan Akhir
}

\section{c. Sederhana dan Cepat}

Salah satu hal yang dituntut public ketika memasuki sebuah proses peradilan, mereka harus mendapat kemudahan yang didukung sistem. Proses yang berbelit-belit akan membuahkan kefrustasian dan ketidakadilan, akan tetapi harus diingat bahwa tindakan yang procedural harus pula menjamin pemberian keadilan, dan proses yang sederhana harus pula menjamin adanya ketelitian dalam pengambilan keputusan. Dengan demikian maka undue procedure and delays harus dieliminasi atau setidaknya ditekan seminim mungkin, sebagaimana dicerminkan dalam International Covenant on Civil and Political Rights Pasal 9 butir 3 dan Pasal 14 butir 3c (...everyone shall be entitled to the following minimum guarantee, in full equality... to be tried without undue delay...).

\section{d. Efektif dan Efisien}

Suatu proses peradilan harus dirancang untuk mencapai sasaran yang dituju yaitu hukum dan keadilan. Selanjutnya seluruh sub sistem dalam melaksanakan tugas dan kewajiban mereka harus pula:

1) Berdaya guna dan berhasil guna;

2) Dengan memanfaatkan sumber daya manusia yang berkualitas dan professional;

3) Menggunakan sedikit mungkin sumber dana.

\section{e. Akuntabilitas}

Pemberian kekuasaan membawa konsekuensi adanya akuntabilitas, dalam kerangka pelaksanaan akuntabilitas ada beberapa hal yang harus diperhatikan, yaitu adanya:

1) Ketaatan pada hukum

2) Prosedur yang jelas, adil, dan layak, serta

3) Mekanisme control yang efektif

Yang dapat dilakukan secara: 
1) Internal (oleh lembaga yang bersangkutan sendiri, baik oleh peer group maupun atasan)

2) Eksternal (oleh pihak diluar lembaga)

3) Horizontal (oleh lembaga lain dalam hubungan horizontal), maupun

4) Vertikal (oleh pihak yang mempunyai hubungan vertical dengan personil atau lembaga).

\section{f. Transparansi}

Makna transparansi bukan merupakan keterbukaan yang tanpa batas akan tetapi sesuai dengan tingkat pemeriksaan dan kebutuhan, asalkan ada kesempatan bagi public untuk melakukan control dan koreksi. Misalnya keterbukaan dalam sidang pengadilan merupakan suatu keharusan akan tetapi pemeriksaan oleh lembaga kepolisian tentunya tidak terbuka untuk umum.

Pasal 10 Universal Declaration of Human Rights dengan tegas menentukan bahwa "everyone is entitled in full equality to a fair and public hearing by an independent and impartial tribunals of any criminal charges against him." Erat hubungannya dengan konsep ini adalah kebebasan untuk memperoleh informasi dengan syarat tidak membahayakan berjalannya proses peradilan.

Proses sistem peradilan pidana berhubungan dengan sistem pemasyarakatan. Hal ini karena pemasyarakatan merupakan bagian akhir dari peradilan pidana.

Pembinaan narapidana sebagaimana dimaksud dalam Undang-Undang 12 Tahun 1995 dilakukan berdasarkan Pancasila pemikiran-pemikiran baru mengenai fungsi pemidanaan yang tidak lagi sekadar penjeraan tetapi juga merupakan suatu usaha rehabilitasi dan reintegrasi social Warga Binaan Pemasyarakatan sudah melahirkan suatu sistem pembinaan yang sejak lebih dari 30 tahun yang lalu dikenal dan dinamakan sistem pemasyarakatan.

Terorisme memiliki kaitan antara delik politik dan delik kekerasan, sehingga pandangan tentang terorisme seringkali bersifat subjektif. ${ }^{10}$ Dalam Perpu No. 1 Tahun 2002 sebenarnya ada pasal-pasal yang sangat riskan melanggar HAM yaitu Pasal 46 tentang Asas Retroaktif. Kemudian pada Bulan Juli 2004 MK menyatakan bahwa UU No. 15 Tahun 2003 tentang Penetapan Perpu No 1 Tahun 2002 tentang pemberantasan tindak pidana terorisme pada peledakan Bom Bali tanggal 12 Oktober 2002 tidak memiliki kekuatan yang mengikat.

Menurut MK, terorisme adalah kejahatan biasa yang sangat kejam, maka kejahatan terorisme untuk Bom Bali tidak bisa diberlakukan asas retroaktif. Ini artinya, terorisme bukan merupakan kejahatan terhadap genosida, kejahatan kemanusiaan, kejahatan perang dan kejahatan agresi. UU No. 15 Tahun 2003 tidak bisa diberlakukan Asas Retroaktif sebab hal tersebut bertentangan dengan Pasal 1 ayat (3) dan Pasal 28 i ayat (1) Undang-Undang Dasar $1945 .^{11}$ Hal ini tentunya menimbulkan kontroversi para praktisi hukum di Indonesia sebab keputusan MK tersebut hanya memperhatikan Hak Asasi para pelaku Terorisme saja tidak mempertimbangkan akibat dari terorisme itu sendiri termasuk para korban, keluarga korban, masyarakat pada umumnya bahkan akibat terorisme itu akan menyebabkan persepsi negatif bangsa-bangsa dunia terhadap indonesia bahwa indonesia merupakan sarang terorisme dan beranggapan bahwa situasi keamanan indonesia tidak aman.

Di lingkup internasional pengertian terorisme masih ada perdebatan alot. Perdebatan tersebut berputar pada apakah terorisme bisa dimasukkan sebagai kejahatan terhadap kemanusian (crimes againts humanity) atau kejahatan luar biasa (extra ordinary crimes), tetapi bukan sebagai kejahatan kemanusian.

10 Dr. Indrianto SenoAdjie , SH, MH, "Terorisme" Perpu No. 1 Tahun 2002 dalam perspektif hukum pidana, Hal 35.

${ }^{11}$ Amir Syamsuddin, “ Menegakkan Hukum Tanpa Rasa Keadilan", Kompas Cyber Media, 30 Juli 2004 
International Criminal Court (ICC) adalah lembaga prospektif yang seharusnya tidak hanya menerapkan yurisdiksinya terhadap kejahatan-kejahatan yang ditentukan oleh Statuta Roma Tahun 1998. ${ }^{12}$ Dalam hal ini , asas legalitas tetap dipandang sebagai asas fundamental. Namun berkaitan dengan yurisdiksi ICC , asas ini bisa disimpangi apabila negara yang bersangkutan telah membuat pernyataan bahwa negara tersebut bisa menerima pelaksanaan yurisdiksi oleh pengadilan yang berkaitan dengan kejahatan masa lalu. Bertitik tolak dari pembahasan mengenai yurisdiksi ICC diatas, maka sewajarnyalah bahwa kejahatan terorisme termasuk kejahatan terhadap kemanusiaan sebab korbannya massal dan juga menghancurkan kemanusiaan serta peradaban.

\section{Sisi Negatif Pendekatan Legal Formal}

Kebijakan yang terlalu bertumpu kepada pendekatan legal formal dan juga bersifat represif, perlu dikaji ulang karena bukan saja tidak mampu mengatasi masalah terorisme tetapi justeru bisa meningkatkan tindakan kekerasan semacam itu di masa depan. ${ }^{13}$ Pemerintah perlu memikirkan alternatif pendekatan dalam menyelesaikan masalah terorisme di tanah air diluar pendekatan legal formal / represif.

Ada beberapa hal efek negatif bisa menyebabkan cara penyelesaian berbasis legal formal/represif itu kurang mampu menyelesaikan masalah terorisme yaitu: ${ }^{14}$ pertama Logika dibelakang pendekatan melalui pendekatan melalui

12 Amir Syamsuddin, " Menegakkan Hukum Tanpa Rasa Keadilan”, Kompas Cyber Media, 30 Juli 2004

${ }^{13}$ Frans Hendra Winata, " Terorisme itu Kejahatan Luar Biasa", Kompas Cyber Media, http://www.kompas.com. (11

September 2004), Diakses tanggal 15 Agustus 2017

14 Dafri Agussalim, “ Mencari Cara Memerangi Terorisme", Kompas Cyber Media, (Kamis 23 Agustus 2003). Di akses tanggal 15 Agustus 2017 mekanisme hukum itu berlawanan dengan logika yang dianut para teroris itu sendiri. Sanksi pidana pada dasarnya untuk mencegah agar sesorang tidak melakukan tindakan tersebut atau menghukum mereka yang melakukan tindakan yang tidak dibolehkan dengan harapan pelaku dan orang lain tidak melakukan hal yang sama kelak dengan cara menerapkan sanksi fisik bagi para pelanggar, mulai yang teringan sampai dengan yang terberat seperti hukuman mati. Tetapi, logika itu berlawanan dengan logika para pelaku teroris yang bertindak melampaui rasa takut untuk melakukannya bahkan mereka rela mati untuk mewujudkan tujuan mereka.

Kedua Cara memerangi terorisme yang bersifat legal formal dan represif seperti ini dapat menimbulkan efek balik yang berlawanan dengan tujuan semula untuk memerangi terorisme.

Keberhasilan membuat perangkat hukum yang baik belum tentu memberikan dampak positif dalam mewujudkan maksud dan juga tujuan hukum. Sebagus apapun produk hukum formal yang ada tidak akan ada artinya tanpa disertai penerapan yang baik. Ironisnya, Indonesia dipandang sebagai negara yang pandai membuat perangkat hukum namun masih lemah penerapannya. Hal ini jika dibiarkan akan mempengaruhi tingkat kepercayaan masyarakat terhadap hukum itu sendiri.

\section{E. Kesimpulan}

Terorisme timbul dengan dilatar belakangi berbagai sebab dan motif. Namun patut kita sadari bahwa terorisme bukan merupakan ideologi atau nilai-nilai tertentu dalam ajaran agama. Terorisme merupakan strategi, instrumen dan atau alat mencapai tujuan. Penerapan UU anti terorisme di dalam No 15 Tahun 2003 sangat berpotensi mengakibatkan pelanggaran Hak Asasi Manusia bagi para tersangka terorisme dan tidak memberikan efektifitas untuk mengurangi orang untuk bertindak sebagai teroris. Pemberian 
wewenang yang terlalu luas bagi aparat untuk memberantas terorisme tanpa disertai tanggungjawab dalam pelaksanaannya akan mengakibatkan suatu terorisme baru yang dilakukan terhadap negara terhadap warga negaranya atau State Terorisme.

Indonesia merupakan demokrasi yang menjunjung tinggi nilai-nilai kemanusiaan. Namun, saat ini Indonesia masih menggunakan pendekatan kekerasan dalam menangani terorisme misalnya dengan penyergapan, pengejaran, pembunuhan, penangkapan oleh aparat keamanan. Keinginan yang besar dalam gerakan kontra terorisme seringkali mengabaikan nilai-nilai HAM di dalamnya. Terdapat beberapa dugaan pelanggaran hukum dan ham yang kerap dilakukan oleh polisi dan Densus 88, dimana bentuk pelanggaran yang dilakukan secara umum berupa penggunaan kekuatan berlebihan (excessive Use of Force) yang mengakibatkan tewasnya si tertuduh, kemudian pelanggaran hak atas rasa aman serta ketenangan dari masyarakat, penembakan salah sasaran (shooting innocent civilians), penyiksaan dan perlakuan tidak manusiawi lainnya, penangkapan dan penahanan paksa serta salah tangkap. Aksi terorisme memang merupakan suatu aksi yang melanggar HAM namun cara-cara untuk memperlakukan para pelaku terorisme perlu untuk mengedepankan aspek HAM karena isu HAM berpengaruh terhadap upaya penanggulangan terorisme.

Kearifan lokal dalam masyarakat komunal dapat dijadikan media untuk mengoptimalkan dan menguatkan peran masyarakat dalam penanggulangan kelompok radikal dan teroris dapat menjadi pilihan untuk meminimalisasi efek negatif yang ditimbulkan oleh pendekatan keamanan (hard approach).

\section{Saran}

Untuk memerangi tindakan terorisme pemerintah perlu memikirkan pendekatan yang tidak legalis represif terhadap terorisme salah satunya antara lain memikirkan kemungkinan rekonsialisasi dan terbukanya komunikasi intensif antara pemerintah-masyarakat dan unsur-unsur di dalam masyarakat itu sendiri baik melalui pendekatan Agama maupun Budaya.

\section{DAFTAR PUSTAKA}

\section{BUKU :}

Abu Ahmadi, Ilmu Pendidikan, Jakarta: Bumi Aksara, 2000

Alex Conte, Human Rights in the Prevention and Punishment of Terrorism, Commonwealth Approaches: The United Kingdom, Canada, Australia, and New Zealand, Springer, London, 2010.

Barry Buzan, Ole Waever, Jaap de Wilde, Security, A New Framework for Analysis, Lynne Reinner Publishers, London, 1998.

Bryan A. Garner, Black's Law Dictionary. Edisi Delapan, West Publishing CO, Amerika Serikat, 2004.

Dr. Indrianto SenoAdjie , SH, MH, “Terorisme” Perpu No. 1 Tahun 2002 dalam perspektif hukum pidana. 
Muhammad Taufiq, Keadilan Substansial Memangkas Rantai Birokrasi Hukum, Cetakan I, Pustaka Pelajar, Yogyakarta, 2014.

Muhammad Taufiq, Serial Terorisme Demokrasi 2 : Densus dan Terorisme Negara, Cetakan I, Pustaka Pelajar, Yogyakarta, 2016.

Steve Tsang (.ed), Intelligence and Human Rights In The Era Of Global Terrorism, Praeger Security International, London, 2007.

Sukawarsini Djelantik, Terorisme Tinjauan Psiko-Politis. Peran Media, Kemiskinan, dan Keamanan Nasional, Yayasan Obor Indonesia, Jakarta, 2010.

Soetandyo Wigjosoebroto, Hukum dan Metode-Metode Kajiannya, BPHN, Jakarta, 1980.

Abdul Latief. 2010. Jaminan UUD 1945 dalam Proses Hukum yang Adil, dalam Jurnal Konstitusi Volume 1 Nomor 1 Februari 2010

Dr. Indrianto SenoAdjie, SH, MH, “Terorisme” Perpu No. 1 Tahun 2002 dalam perspektif hukum pidana.

Mahrus Ali. 2007. Sistem Peradilan Pidana Progresif: Alternatif dalam Penegakkan Hukum Pidana, dalam Jurnal Ilmu Hukum Vol. 14 No. 2 April 2007 Hlm. 217

T. Nasrullah, Tinjauan Yuridis Aspek Hukum Materil Maupun Formil Terhadap UU No. 15/2003 Tentang Pemberantasan Tindak Pidana Terorisme, Jurnal Kriminologi Indonesia Vol.4 No.I September 2005: 65-76.

\section{UNDANG-UNDANG:}

Undang-Undang No. 39 Tahun 1999 tentang Hak Asasi Manusia (Lembaran Negara Republik Indonesia Tahun 1999 Nomor 165)

Undang-Undang Republik Indonesia Nomor 8 Tahun 1981 Tentang Hukum Acara Pidana (Tambahan Lembaran Negara Republik Indonesia Nomor 3209)

Undang-Undang No. 5 Tahun 1998 tentang Pengesahan Konvensi Menentang Penyiksaan dan Perlakuan atau Hukuman Lain yang Kejam, Tidak Manusiawi, dan Merendahkan Martabat Manusia (Tambahan Lembaran Negara Republik Indonesia Nomor 3783)

Undang-undang No. 9 Tahun 2013 tentang Pencegahan dan Pemberantasan Tindak Pidana Pendanaan Terorisme (Tambahan Lembaran Negara Republik Indonesia Nomor 5406)

Undang-Undang No. 2 Tahun 2002 Tentang Kepolisian Negara Republik Indonesia (Lembaran Negara Republik Indonesia Tahun 2002 Nomor 2) 
Peraturan Kepala Kepolisian Negara Republik Indonesia No. 14 Tahun 2011 Tentang Kode Etik Profesi Kepolisian Negara Republik Indonesia (Berita Negara Republik Indonesia Tahun 2011 Nomor 608)

\section{Sumber Lainnya:}

http://www.komisihukum.go.id.Administrasi Peradilan-Laporan Akhir

Amir Syamsuddin, “ Menegakkan Hukum Tanpa Rasa Keadilan”, Kompas Cyber Media, 30 Juli 2004

Dafri Agussalim, “Mencari Cara Memerangi Terorisme”, Kompas Cyber Media, (Kamis 23 Agustus 2003). Di akses tanggal 15 Agustus 2017

Dr. Petrus Reinhard Golose, Strategi Penguatan Hukum dan Deradikalisasi dalam Mengeliminasi Tindakan Pidana Terorisme.

Frans Hendra Winata, " Terorisme itu Kejahatan Luar Biasa" , Kompas Cyber Media, http://www.kompas.com. (11 September 2004), Diakses tanggal 15 Agustus 2017

KontraS, Potret Buram Densus 88 Anti Teror Dalam Bingkai Hak Asasi Manusia, Diakses di http://www.kontras.org/buletin/indo/DENSUS.pdf, Pada 15 Agustus 2017 Pukul 12.30 WIB

Prof. Adrianus Meliala, Ph.D, Rule of Law dalam Kontra Terorisme. Kuliah Terorisme dan Kontraterorisme, Program Pascasarjana Kajian Stratejik Intelijen Universitas Indonesia. Jakarta, Pada 2 November 2015

Usman Hamid, Pengembangan Pemikiran dan Solusi Strategis Penanggulangan Aksi Terorisme dalam Perspektif Hukum dan HAM, hlm 1 